\title{
Photosynthesis dependent acidification of perialgal vacuoles in the Paramecium bursaria/Chlorella symbiosis: visualization by monensin
}

\section{Rapid Communication}

\author{
A. Schüßler and E. Schnepf* \\ Zellenlehre, Fakultät für Biologie, Universität Heidelberg, Heidelberg
}

Received December 30, 1991

Accepted January 7, 1992

\begin{abstract}
Summary. After treatment with the carboxylic ionophore monensin the Chlorella containing perialgal vacuoles of the "green" Paramecium bursaria swell. The Paramecium cells remain motile at this concentration for at least one day. The swelling is only observed in illuminated cells and can be inhibited by DCMU. We assume that during photosynthesis the perialgal vacuoles are acidified and that monensin exchanges $\mathrm{H}^{-+}$ions against monovalent cations (here $\mathrm{K}^{+}$). In consequence the osmotic value of the vacuoles increases. The proton gradient is believed to drive the transport of maltose from the symbiont into the host. Another but light independent effect of the monensin treatment is the swelling of peripheral alveoles of the ciliates, likewise indicating that the alveolar membrane contains an active proton pump.
\end{abstract}

Keywords: Paramecium bursaria; Endosymbiontic Chlorella; Perialgal vacuoles; Sugar transport; Photosynthesis; Proton pumps; Monensin.

Abbreviations: HEPES N-(2-hydroxyethyl)piperazine-N'-2-ethane sulfonic acid; DCMU 3-(3, 4-dichlorophenyl)-1, I-dimethylurea.

\section{Introduction}

Some Chlorella species live as endosymbionts in fresh water animals and protists (for survey, see Smith and Douglas 1987, Reisser 1986). They are photosynthetically active and supply their hosts with organic nutrients. The symbiontic consortium Paramecium bursaria/Chlorella behaves as an autotrophic organism in inorganic culture media. Experiments with isolated strains of symbiontic Chlorella of Paramecium bursaria

\footnotetext{
* Correspondence and reprints: Zellenlehre, Universität Heidelberg, Im Neuenheimer Feld 230, D-W-6900 Heidelberg, Federal Republic of Germany.
}

have shown that the algae secrete high amounts of maltose (Muscatine 1967; Reisser 1981, 1986; Kessler et al. 1991). Up to $45 \%$ of the photosynthetically fixed carbon is released as maltose at a $\mathrm{pH}$ optimum of about 4.5 , whereas at neutral $\mathrm{pH}$ only low amounts of sugars are secreted. In situ the algae transfer up to $57 \%$ to totally fixed carbon to the Paramecium cells (Reisser 1976). The low $\mathrm{pH}$ is the only factor known to increase sugar secretion. The $\mathrm{pH}$ dependence of sugar secretion with an optimum of about $\mathrm{pH} 5$ is also reported for other isolated symbiontic Chlorella strains, e.g., from Stentor polymorphus (Reisser 1981), Hydra viridis (Cernichiari et al. 1969, Smith and Douglas 1987, Kessler et al. 1991), Spongilla fluviatilis (Fischer et al. 1989) and the heliozoan Acanthocystis turfacae (Matzke et al. 1990). For the latter two algae a $\mathrm{pH}$ dependent active transport of sugars against a concentration gradient was shown.

It is, however, not known as yet whether in situ the sugar transport depends also on a proton gradient. Within the host single endosymbiontic Chlorella cells are included in a perialgal vacuole with the vacuole membrane closely surrounding the alga in a distance of about $0.05 \mu \mathrm{m}$ (Reisser 1986). We, therefore, tried to visualize an acidification of the perialgal vacuoles of Paramecium bursaria with the carboxylic ionophore monensin.

Monensin complexes monovalent cations and releases them after protonation (Sandeaux et al. 1982). In this way cations are exchanged against protons, and the 
acidification of a compartment is transformed into an increase of its osmotic value, resulting in its swelling. Monensin was thus used to demonstrate active proton pumps, e.g., in the Golgi apparatus (Mollenhauer et al. 1983, Boss 1984), in irradiated chloroplasts of Funaria protonemata (Schnepf 1983), and in granules of chromaffine cells (Geisow and Burgoyne 1982). The shrinkage of the mitochondrial matrix after treatment with monensin is probably due to the same mechanism; it does not affect ATP production (Tartakoff et al. 1981, Tartakoff 1983).

In addition we used DCMU, a blocker of electron flow in photosystem II (Kleinig and Sitte 1986) to characterize the monensin effects in more detail.

\section{Material and methods \\ Paramecium bursaria, kindly supplied by Prof. Dr. W. Wiessner, Planzenphysiologisches Institut, Universität Göttingen, was culti- vated in Erlenmeyer flasks at $20^{\circ} \mathrm{C}$ and a $20: 4 \mathrm{~h}$ light: dark regime in an inorganic medium [Knop solution, consisting of $0.25 \mathrm{~g} / 1$ $\mathrm{KH}_{2} \mathrm{PO}_{4}, 0.25 \mathrm{~g} / 1 \quad \mathrm{KCl}, 0.25 \mathrm{~g} / 1 \quad \mathrm{MgSO}_{4} \times 7 \mathrm{H}_{2} \mathrm{O}, 1 \mathrm{~g} / 1 \mathrm{Ca}\left(\mathrm{NO}_{3}\right)_{2}$ $\times 4 \mathrm{H}_{2} \mathrm{O}$ and $1 \mathrm{ml} / \mathrm{Fe}$-EDTA-complex (Jacobsen)] which was ad- justed to pH 7.0 with 0.1 M HEPES (Serva, Heidelberg). Stock so- lutions of monensin (Calbiochem, La Jolla, California), DCMU (Serva, Heidelberg) (both $10^{-2} \mathrm{M}$ in ethanol), were used to obtain media with final concentrations of $10^{-5}-10^{-4} \mathrm{M}$ monensin and $10^{-5}-10^{-4} \mathrm{M}$ DCMU. DCMU was given simultaneously or $3 \mathrm{~h}$ before monensin treament to inhibit photosynthesis. The Parame- cium cells were incubated for up to $24 \mathrm{~h}$, partly in light, partly in darkness. We used corresponding concentrations of ethanol for con- trol experiments; they did not show any effect. For closer inspection and to photograph the cells they were immobilized by adding $\mathrm{NiCl}_{2}$ from $20 \mathrm{mM}$ stock solution to the medium just before observation on a final concentration of $4 \times 10^{-4} \mathrm{M}$ (Larsen and Satir 1991). This treatment did not affect the appearance of the Paramecium compartments.}

\section{Results}

In concentrations higher than $10^{-4} \mathrm{M}$ monensin damaged letally Paramecium bursaria. At a concentration of $10^{-4} \mathrm{M}$ the ciliates remained motile for at least one day in darkness or at low light intensities. Treatment with $10^{-5} \mathrm{M}$ monensin caused only slight effects. At concentrations of $10^{-4}$ and $5 \times 10^{-5} \mathrm{M}$ perialgal vacuoles of illuminated Paramecium cells began to swell within $3-4 \mathrm{~h}$ (Fig. 1). They continued to increase in size, became very big after $6 \mathrm{~h}$ in all cells (Fig. 2 ) and tended to fuse then (Fig. 3). The about 2.5-fold increase in diameter of the perialgal vacuole after $6 \mathrm{~h}$ corresponds to a 200 -fold increase of the perialgal volume. The Chlorella cells were freely suspended within a vacuole, i.e., they were not in contact with the vacuolar membrane, and looked normally. After prolonged treatment with monensin the previously swollen perialgal vacuoles shrunk in some Paramecium cells.
The monensin induced swelling of the perialgal vacuoles was reversible. They became normal again within $12 \mathrm{~h}$ when the cells were retransferred into the normal culture medium. In Paramecium cells incubated with monensin in darkness the perialgal vacuoles did not swell (Figs. 4 and 5). The cells then showed cyclosis with algae in digestion and some swollen digestive vacuoles, as well as smaller clear vacuoles which partly were located in the periphery without any movement. Independent of the illumination was the formation of peripheral blebs, arising from peripheral alveoles (electron microscopy observations, not shown). At $5 \times 10^{-5} \mathrm{M}$ monensin, the first small protruding vesicles became visible within a few minutes. Later 1-4 big blebs were observed which reached a diameter of about $30 \mu \mathrm{m}$ (nearly cell diameter) (Figs. 3-5). These vesicles had clear, translucent contents. After longer incubation the cells rounded off more and more. This was more expressed in illuminated cells where the swollen perialgal vacuoles promoted the rounding.

In the presence of DCMU $\left(10^{-4}-10^{-5} \mathrm{M}\right)$ the monensin induced swellings of the perialgal vacuoles were considerably reduced if both agents were supplied simultaneously and did not occur at all if the Paramecium cells were incubated $3 \mathrm{~h}$ with DCMU before monensin was added (Figs. 7 and 8). The effects were then similar as after monensin treatment in darkness: cyclosis and small clear vesicles occurred as well as swollen alveoles.

\section{Discussion}

The swelling of the perialgal vacuoles after monensin treatment indicates that they become acidified under conditions when the symbiontic Chlorella cells are photosynthetically active. This supports the assumption that also in situ maltose is transported via a sugar/ proton antiport form the Chlorella cell into the perialgal vacuole. The transport from the perialgal vacuole into the cytosol of the Paramecium cells could be passive or be driven by a proton cotransport (Willenbrink 1987).

The absence of the swellings in darkness and after treatment with DMCU correlates with the strong decrease of maltose secretion under this conditions. After treatment with $10^{-6} \mathrm{M} \mathrm{DCMU}$ the rate of secreted maltose decreases to $5 \%$ (Reisser 1976). The source of the residual release could be the decomposition of starch. It is probable that the proton gradient is formed by the Chlorella cells, since the swelling is coupled with photosynthesis. It can, however, not be excluded that the occurrence of maltose within the perialgal vacuole 
1

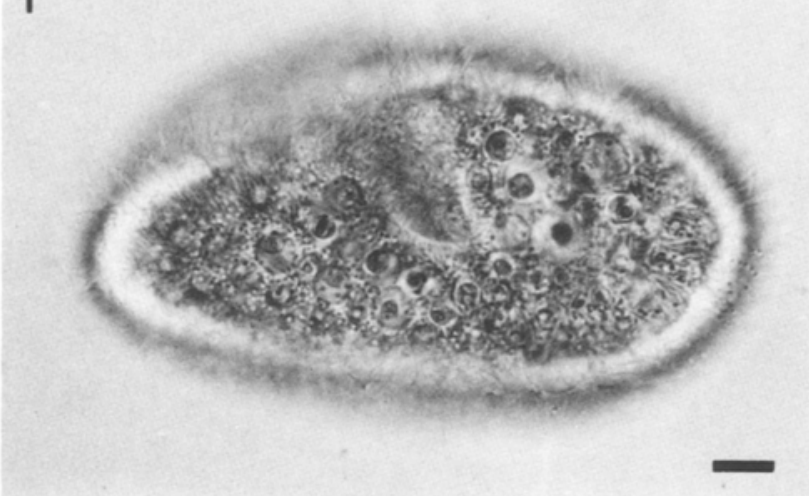

3

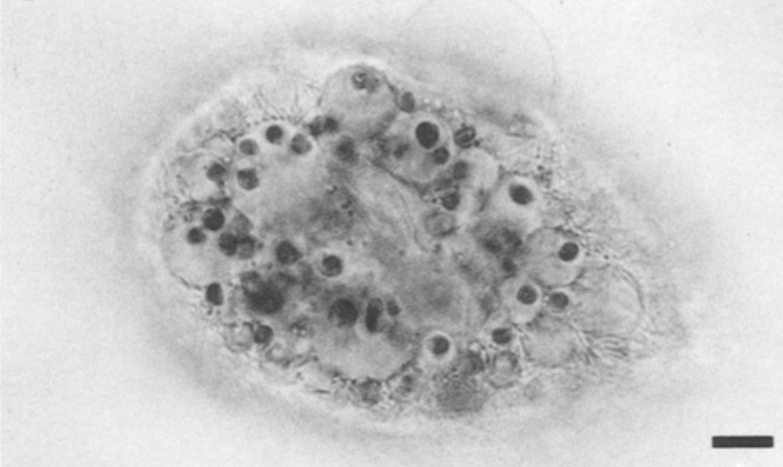

5

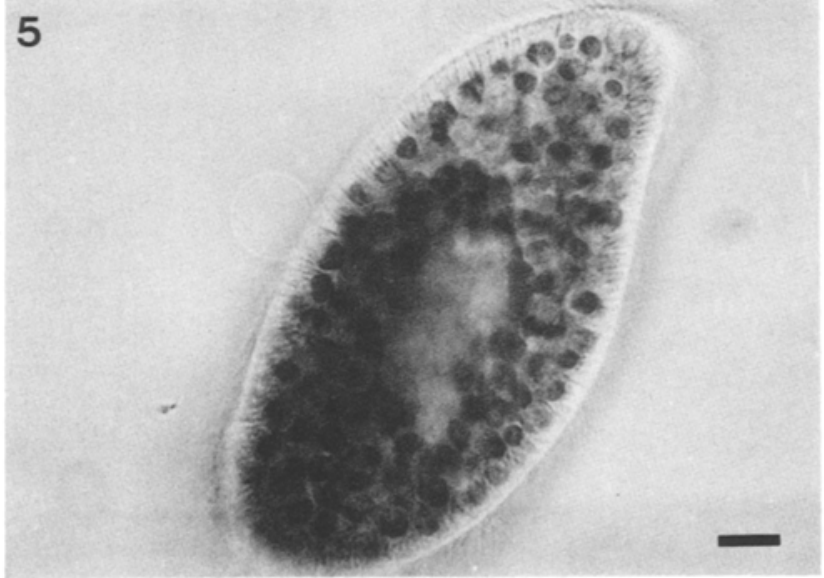

7

30
2

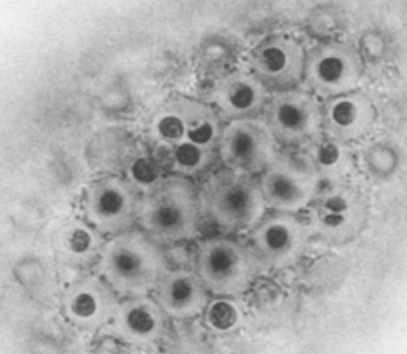

4

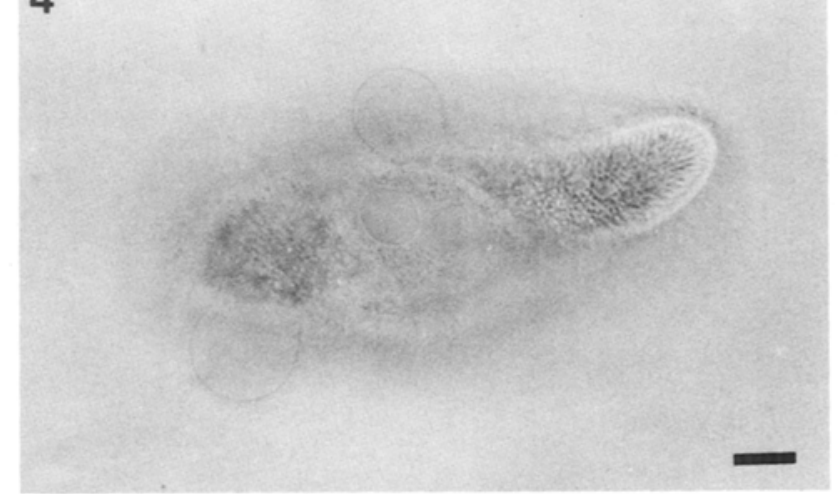

6
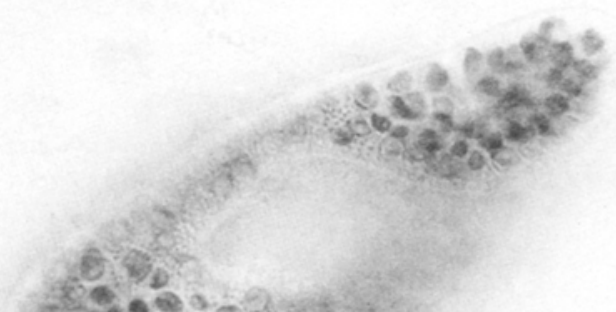

(⿻)丨丿巾.

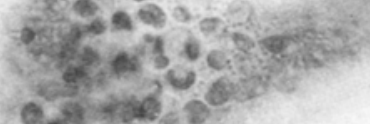

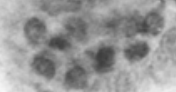

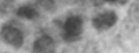

8

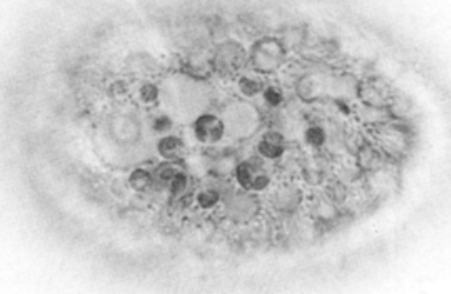

n? 
triggers a proton pump in the vacuolar membrane. The observation that the Chlorella cells are not attached to the membrane of swelling perialgal vacuoles indicates that those contacts are perhaps less important than frequently suggested (Reisser 1990).

The swollen centrally located vacuoles within the Paramecium cells which are incubated in darkness or DMCU seem to be digesting vacuoles becoming acidified, meaning that the algae are not longer protected against digestion (Hohmann et al. 1982, Reisser 1986). Under these conditions the perialgal membrane becomes altered (Reisser 1976). The clear small vacuoles are perhaps swollen primary lysosomes.

The swelling of the peripheral alveoles after monensin treatment indicates that their membrane contains an active proton pump. This effect is indepentent of illumination and the presence of DCMU. The peripheral alveoles have been shown to sequester $\mathrm{Ca}^{2+}$ ions by a $\mathrm{Ca}^{2+}$-ATPase (Stelly et al. 1991) and are believed to control calcium-regulated processes that take place in the immediate vicinity of the alveoles, for example trichocyst exocytosis stimulation, ciliary beating or cytoskeletal elements dynamics during division. The meaning of the acidification remains obscure.

Though monensin has a 10-fold higher affinity to $\mathrm{Na}^{+}$ than to $\mathrm{K}^{+}$ions (Pressman 1976), in the present experiments $\mathrm{K}^{+}$ions are probably used for the exchange against protons. The medium does no contain $\mathrm{Na}^{+}$ ions, and the tiny traces perhaps liberated from the glass vessels are surely not high enough to be osmotically effective.

\section{Acknowledgements}

We thank Prof. Wiessner, Göttingen, for supplying us with Paramecium bursaria and the Deutsche Forschungsgemeinschaft for support.

\section{References}

Boss WF (1984) Monensin-induced swelling of Golgi apparatus cisternae mediated by a proton gradient. Eur J Cell Biol 34: 1-8

Cernichiari E, Muscatine L, Smith DC (1969) Maltose excretion by the symbiotic algae of Hydra viridis. Proc $\mathbf{R}$ Soc Lond [Biol] 173: $557-576$

Fischer A, Meindl D, Loos E (1989) Glucose excretion by the symbiotic Chlorella of Spongilla fluviaitis. Planta 179: 251-256

Geisow MJ, Burgoyne RD (1982) Effect of monensin on chromaffin cells and the mechanism of organelle swelling . Cell Biol Int Rep 6: 933-939

Hohman TC, McNeil PL, Muscatine L (1982) Phagosome-lysome fusion inhibited by algal symbionts of Hydra viridis. J Cell Biol 94: $56-63$

Kessler E, Kauer G, Rahat M (1991) Excretion of sugars by Chlorella species capable and incapable of symbiosis with Hydra viridis. Bot Acta 104: 58-63

Kleinig H, Sitte P (1986) Zellbiologie, 2nd edn. Fischer, Stuttgart

Larsen J, Satir P (1991) Analysis of $\mathrm{Ni}^{2+}$-induced arrest of Paramecium axonemes. J Cell Sci 99: 33-40

Matzke B, Schwarzmeier E, Loos E (1990) Maltose excretion by the symbiotic Chlorella of the helizoan Acanthocystis turfacae. Planta 181: $593-598$

Mollenhauer HH, Motré DJ, Droleskey R (1983) Monensin affects the trans half of Euglena dictyosomes. Protoplasma 114:119124

Muscatine L, Karakashian SJ, Karakashian MW (1967) Soluble extracellular products of algae symbiotic with a ciliate, a sponge and a mutant Hydra. Comp Biochem Physiol 20: 1-12

Pressmann BC (1976) Biological applications of ionophores. Annu Rev Biochem 45: 501-528

Reisser W (1976) Die stoffwechselphysiologischen Beziehungen zwischen Paramecium bursaria Ehrbg. und Chlorella spec., in der Paramecium bursaria-Symbiose. II. Symbiose-spezifische Merkmale der Stoffwechselphysiologie und der Cytologie des Symbioseverbandes und ihre Regulation. Arch Microbiol 111: 161170

- (1981) The endosymbiontic unit of Stentor polymorphus and Chlorella sp. Morphological and physiological studies. Protoplasma 105: 273-284

- (1986) Endosymbiotic associations of freshwater protozoa and algae. Prog Protistol 1: 195-214

- (1990) Participation of algal cell wall surface structures in the formation of the host-symbiont-interface of endocytobiotic systems. Exp Phycol 1: 55-68

Figs. 1-8. Paramecium bursaria. Bars: $10 \mu \mathrm{m}$

Fig. 1. Monensin, $4 \mathrm{~h}, 5 \times 10^{-5} \mathrm{M}$, light. First significant swellings of perialgal vacuoles

Fig. 2. Monensin, $6 \mathrm{~h}, 5 \times 10^{-5} \mathrm{M}$, light. The swellings are stronger and first perialgal vacuoles have fused

Fig. 3. Monensin, $10 \mathrm{~b}, 5 \times 10^{-5} \mathrm{M}$, light. Many big perialgal vacuoles, frequently fused, one peripheral bleb is in focus

Fig. 4. Monensin, $8 \mathrm{~h}, 5 \times 10^{-5} \mathrm{M}$, darkness. Cell surface with some peripheral blebs

Fig. 5. Monensin, $8 \mathrm{~h}, 5 \times 10^{-5} \mathrm{M}$, darkness. No swollen perialgal vacuoles and a peripheral bleb, algae also in the cell interior in digestion

Fig. 6. Control cell, $0.5 \%$ ethanol, $8 \mathrm{~h}$

Fig. 7. Monensin, DCMU, $8 \mathrm{~h}$, each $5 \times 10^{-5} \mathrm{M}$, light, after $3 \mathrm{~h}$ preincubation with DCMU, $5 \times 10^{-5} \mathrm{M}$. No swellings of the perialgal vacuoles, swollen peripheral alveoles

Fig. 8. As Fig. 7, some empty appearing vacuoles beside non-swollen perialgal vacuoles 
Sandeaux R, Sandeaux J, Gavach C, Bernhard B (1982) Transport of $\mathrm{Na}^{+}$by monensin across biomolecular lipid membranes. Biochim Biophys Acta 684: 127-132

Smith DC, Douglas AE (1987) The biology of symbiosis. E Arnold, London

Stelly N, Mauger J-P, Claret M, Adoutte A (1991) Cortical alveoli of Paramecium: a vast submembraneous calcium storage compartment. J Cell Biol 113: 103-112
Tartakoff AM (1983) Perturbation of vesicular traffic with the carboxylic ionophore monensin. Cell 32: 1026-1028

- Vassalli P (1981) Plasma cell endocytosis: is it related to immunoglobulin secretion? Eur J Cell Biol 26: 188-197

Willenbrink J (1987) Die pflanzliche Vacuole als Speicher. Naturwissenschaften 74: 22-29 